\title{
A CASE OF TRAUMATIC TRANSECTION OF CERVICAL SPINAL CORD BY GLASS
}

\author{
By A. Z. BuczYnski, M.D., and J. Makowski, M.D. \\ Department of Rehabilitation; Medical Academy of Warsaw (Konstancin)
}

DIRECT injuries to the spinal cord in peace time are encountered relatively rarely and they account for only a small proportion of all spinal cord injuries. They are most frequently caused by fire-arms or stab wounds. Because no report of a case like that presented below was found by us in the available literature it was thought worth while to describe it here in detail.

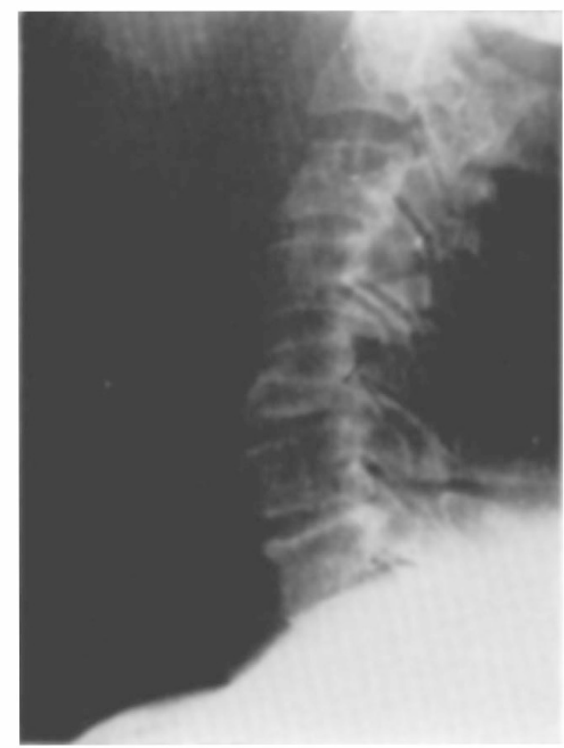

FIG. I

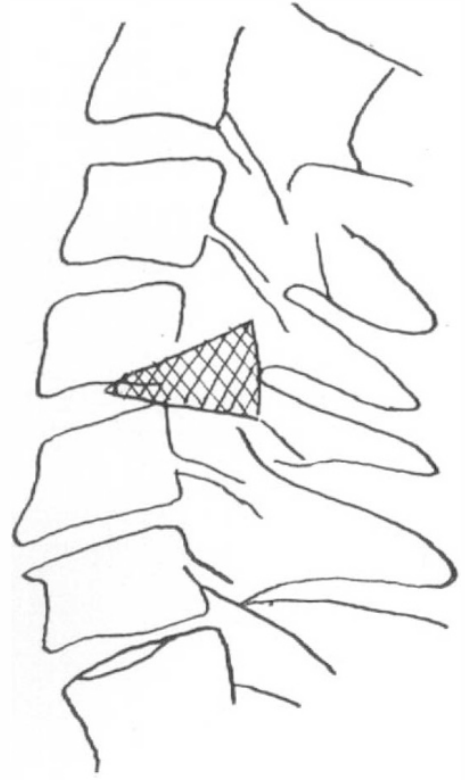

FIG. 2

\section{CASE REPORT}

Patient J. K. was a 5I-year-old male who in December 21972 fell backwards on a glass door and suffered a stab wound of the nape with a glass splinter. He was transported to an ambulance health service station in Warsaw, where a glass fragment $3 \mathrm{~cm}$. long was removed from the wound of his neck, and the wound was sutured. Since tetraplegia was found at the time of the first examination of the patient he was transferred to the Rehabilitation Centre in Konstancin. At the time of admission the findings included: arterial blood pressure $75 / 60 \mathrm{~mm}$. $\mathrm{Hg}$, pulse rate $80 / \mathrm{min}$., presence of profuse secretion in the airways, body temperature $34^{\circ} \mathrm{C}$.

On the neck of the patient, left from the midline at the level of $\mathrm{C}_{4}-\mathrm{C}_{5}$ vertebrae, there was a $5-\mathrm{cm}$ long stab wound present, sutured with single nylon sutures. Neurological abnormalities included abolition of the superficial ar 1 deep sensibility from the level of Th2 downwards. Triceps tendon reflexes were present as well as right biceps tendon reflex, but left biceps reflex were absent. The flexors of the forearm were greatly reduced in power, the remaining muscles of the extremities were paralysed. 


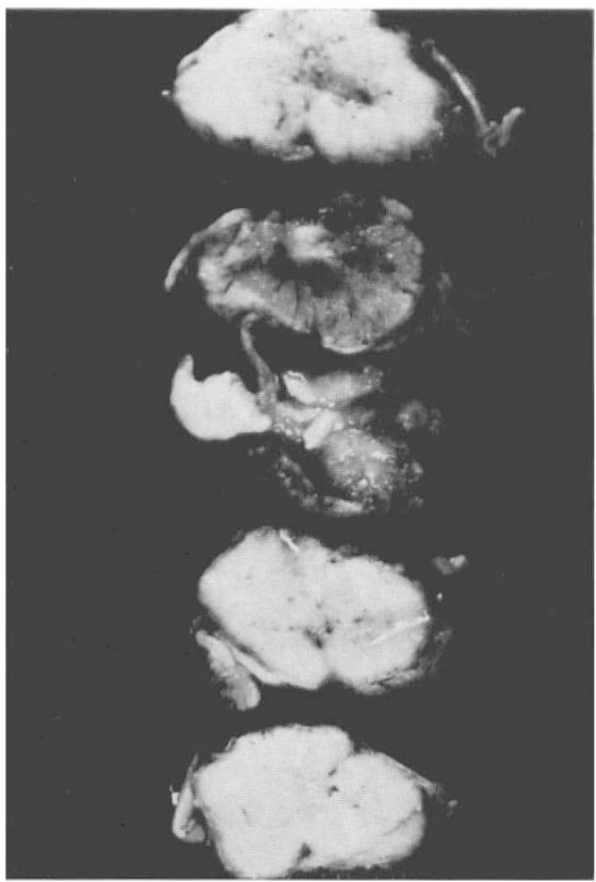

FIG. 3

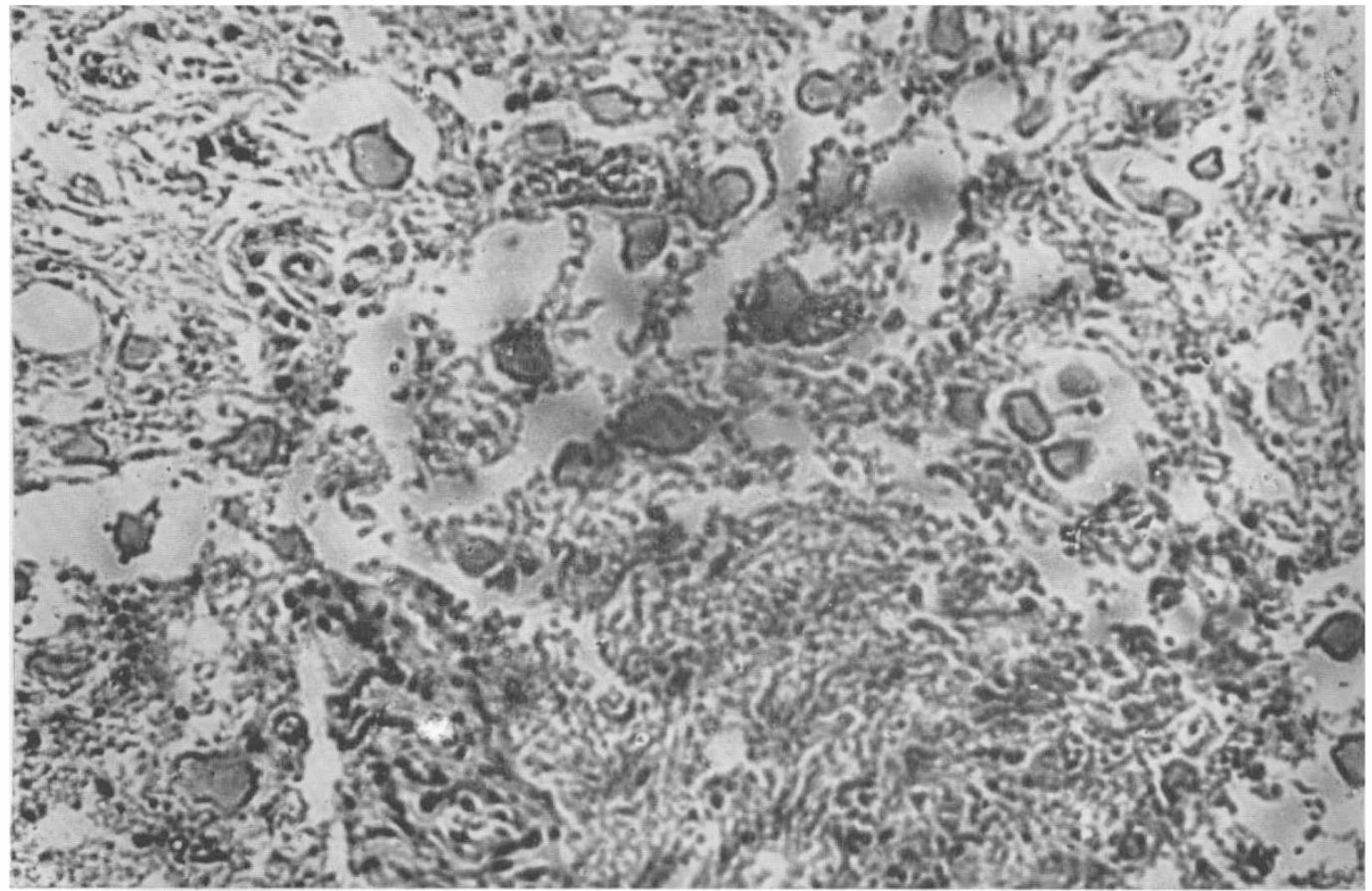

FIG. 4 
Lumbar puncture was performed. The cerebrospinal fluid was clear, its pressure was normal, Queckenstedt's test normal. An X-ray showed the triangular shape of a foreign body at the level of $\mathrm{C}_{4}-\mathrm{C}_{5}$ vertebrae within the vertebral canal. It was suggested that this was a glass fragment (figs. I and 2). An operation was performed several hours after the patient's admission.

From a posterior incision at the levels from $\mathrm{C}_{2}$ to $\mathrm{C} 6$ the spinal column and the vertebral arches were exposed. At the $\mathrm{C}_{4}$ level an opening of $3 \times 15 \mathrm{~mm}$ was found in the tissues and the arch on the left side closely to the spinous process. Hemilaminectomy was performed and the spinal cord was exposed. The meninges were found to be disrupted and three fragments of thick glass were sticking into the cord, two small fragments and one larger one of $25 \times 15 \times 3 \mathrm{~mm}$. The glass splinters were removed and the dura was sutured.

After the operation the condition of the patient remained serious. No improvement in his neurological state was observed. Because of profuse respiratory distress, tracheostomy was performed on the Ioth day after the operation. Despite the administration of agents preventing oedema and resuscitation procedures the patient died after two weeks from cardio-respiratory insufficiency.

Autopsy showed an oval hole $0.5 \times \mathrm{I} .5 \mathrm{~cm}$. with uneven edges and with a blood clot at the medial margin of the dura mater on the posterior aspect of the spinal cord left to the midline. Crumbled whitish soft tissue of the spinal cord was prolapsing through this hole. At a distance of about $2 \mathrm{~cm}$. the spinal cord showed blurring of its normal structure, its diameter was narrowed, its consistency was diminished. Nervous tissue was prolapsing through a hole of the pia and dura mater. On transverse sections severe disintegration of the cord at the level of the lesion with central necrosis was seen with partially preserved marginal part of the white matter (fig. 3).

Microscopic examination of the damaged part of the spinal cord disclosed colliquative necrosis, vacuolisation, erythrocytes and numerous lipophages. In the preserved peripheral part of the cord the nervous tissue showed degenerative changes, with demyelination, blurring of structure and axonal loss.

In the grey matter numerous nerve cells showed central loss of neurofibrils and disintegration of nuclei, while in the white matter most fibres showed presence of demyelination and axonolysis. It may be noted that the changes spread to a greater area $(4-5 \mathrm{~cm}$.) of segments from the segments affected directly by the injury caused by the glass fragments (fig. 4.)

Histopathological examination was carried out by B. Wozniewicz M.D.

\section{SUMMARY}

A case of traumatic transection of the cervical cord by glass is described in detail, including the findings at post-mortem including histology.

\section{RÉSUMÉ}

Un cas de section transversale traumatique de la corde cervicale par du verre est décrit en détail, y compris les résultats de l'autopsie et l'histologie.

\section{ZUSAMMENFASSUNG}

Ein Fall von Durchschneidung des zervikalen Rückenmarks durch ein zerbrochenes Glass wird in Einzelheiten beschrieben einschliesslich post mortem und histologischen Befunden.

$12 / 3-M$ 